\title{
Influence of the use of acids and films in post-harvest lychee conservation ${ }^{1}$
}

\author{
Danielle Fabiola Pereira da Silva ${ }^{2}$, Leila Cristina Rosa de Lins ${ }^{3}$, Elaine Cristina Cabrini, \\ Beatriz Gonçalves Brasileiro ${ }^{5}$ Luiz Carlos Chamhum Salomão ${ }^{6}$
}

\begin{abstract}
Lychee (Litchi chinensis Sonn.) has a high commercial value; however, it has a short shelf-life because of its rapid pericarp browning. The objective of this study was to evaluate the shelf-life of 'Bengal' lychee fruits stored after treatment with hydrochloric acid and citric acid, associated with cassava starch and plastic packaging. Uniformly red pericarp fruits were submitted to treatments: 1-(immersion in citric acid $100 \mathrm{mM}$ for 5 minutes + cassava starch $30 \mathrm{~g} \mathrm{~L}$ ${ }^{1}$ for 5 minutes), 2-(immersion in hydrochloric acid $1 \mathrm{M}$ for 2 minutes + starch cassava $30 \mathrm{~g} \mathrm{~L}^{-1}$ for 5 minutes), 3 (immersion in citric acid $100 \mathrm{mM}$ for 5 minutes + polyvinyl chloride film (PVC, $14 \mu \mathrm{m}$ thick)) and 4-(immersion in hydrochloric acid $1 \mathrm{M}$ for 2 minutes + PVC film). During 20 days, the fruits were evaluated for mass loss, pericarp color, $\mathrm{pH}$, soluble solids and titratable acidity, vitamin $\mathrm{C}$ of the pulp and pericarp and activities of polyphenol oxidase and peroxidase of the pericarp. The treatment with hydrochloric acid associated with PVC was the most effective in maintaining the red color of the pericarp for a period of 20 days and best preservation of the fruit. The cassava starch associated with citric acid, and hydrochloric acid did not reduce the mass loss and did not prevent the browning of lychee fruit pericarp.
\end{abstract}

Key words: Litchi chinensis Sonn., modified atmosphere, quality.

\section{RESUMO}

\section{Influência da utilização de ácidos e filmes na conservação pós-colheita de lichia}

A lichia (Litchi chinensis Sonn.) possui alto valor comercial no mercado, entretanto, apresenta vida útil póscolheita curta, por causa do rápido escurecimento do pericarpo. O objetivo deste trabalho foi avaliar a vida útil póscolheita de lichias 'Bengal', armazenadas após tratamento com ácido clorídrico e ácido cítrico, associados a fécula de mandioca e embalagem plástica. Frutos com pericarpos uniformemente vermelhos foram submetidos aos tratamentos: 1-( imersão em ácido cítrico $100 \mathrm{mM}$ por 5 minutos + fécula de mandioca $30 \mathrm{~g} / \mathrm{L}$ por 5 minutos); 2-( imersão em ácido clorídrico $1 \mathrm{M}$ por 2 minutos + fécula de mandioca $30 \mathrm{~g} / \mathrm{L}$ por 5 minutos); 3-( imersão em ácido cítrico $100 \mathrm{mM}$ por 5 minutos + filme de policloreto de vinila (PVC ,14 $\mu \mathrm{m}$ de espessura)); e 4-( imersão em ácido clorídrico $1 \mathrm{M}$ por 2 minutos + filme de PVC). Durante 20 dias, os frutos foram avaliados quanto à perda de massa fresca, cor do pericarpo, $\mathrm{pH}$, teor de sólidos solúveis e acidez titulável da polpa, vitamina $\mathrm{C}$ do pericarpo e da polpa e atividades de polifenoloxidase e peroxidase do pericarpo. O tratamento com ácido clorídrico associado ao PVC foi o mais efetivo na manutenção da cor vermelha e o que melhor conservou as características de qualidade dos frutos. A fécula de mandioca associada ao ácido cítrico e ácido clorídrico não reduziu a perda de massa e não impediu o escurecimento do pericarpo de lichia.

Palavras-chave: Litchi chinensis Sonn., atmosfera modificada, qualidade.

\footnotetext{
Received for publication on January 10 $0^{\text {th }}, 2012$ and accepted on September $14^{\text {th }}, 2012$.

${ }^{1}$ Finacial support: CAPES, CNPq and FAPEMIG.

${ }^{2}$ Agronomist, Doctor. Post-Doctoral researcher at the Departamento de Fitotecnia, Universidade Federal de Viçosa, Campus Viçosa, Avenida Peter Henry Rolfs, s/n, 36570-000, Viçosa, Minas Gerais, Brasil. danieele@ufv.br (corresponding author)

${ }^{3}$ Agronomist. Master degree student at the Departamento de Fitotecnia, Universidade Federal de Viçosa, Campus Viçosa, Avenida Peter Henry Rolfs, s/n, 36570-000, Viçosa, Minas Gerais, Brasil. leila.lins@ufv.br

${ }^{4}$ Biologist, Doctor. Departamento de Ciências Biológicas e da Saúde, Universidade Federal dos Vales do Jequitinhonha e Mucuri, Rodovia MGT 367, Km 583, 5000, Alto da Jacuba, 39100-000, Diamantina, Minas Gerais, Brasil. eccabrini@gmail.com

${ }^{5}$ Agronomist, Doctor. Instituto Federal de Educação, Ciência e Tecnologia do Sudeste de Minas Gerais, Avenida Monteiro de Castro, 550, Bairro Barra, 36880-000, Muriaé, Minas Gerais, Brasil. beatrizbrasileiro@gmail.com.br

${ }^{6}$ Agronomist, Doctor. Departamento de Fitotecnia, Universidade Federal de Viçosa, Campus Viçosa, Avenida Peter Henry Rolfs, s/n, 36570-000, Viçosa, Minas Gerais, Brasil. 1salomao@ ufv.br
} 


\section{INTRODUCTION}

Lychee (Litchi chinensis Sonn.) is cultivated in tropical and subtropical areas, and its fruit has a high commercial value in the international market (Jiang et al., 2004). Lychee has a bright-red pericarp involving a translucent pulp of great nutritional value (Solomon et al., 2006). However, it has a short shelf life due to the rapid pericarp browning, which can occur in less than 72 hours after harvest (del Aguila et al. 2009).

Pericarp browning has been attributed to desiccation by heat stress, senescence, chilling injuries, pests and diseases. Skin browning commonly results from the degradation of the anthocyanin pigments by oxidases (polyphenol oxidase (PPO), peroxidase (POD) and ascorbic acid oxidase) (Mizobutsi et al., 2010).

The darkening process is triggered when phenolic substrates present in the vacuoles come into contact with the oxidative enzyme that catalyses polyphenol oxidation (PPOs) in the cytoplasm associated with plastid membrane structures. Browning occurs when phenolic substrates, PPOs and oxygen are in optimum conditions of $\mathrm{pH}$, temperature and water activity (Reuck et al., 2011).

Water loss during fruit storage disrupts cellular solute compartmentalization allowing the contact between enzymes and their substrates, promoting undesirable reactions that damage the fruit appearance and, therefore, their commercialization (Lima et al., 2010).

Thus, new attempts to delay or reduce enzymatic oxidation, prevent oxygen-fruit contact and reduce fruit mass losses are important to reduce browning and maintain market quality of litchee under increased storage periods.

Fumigation with sulfur dioxide has been primarily used to prevent lychee pericarp browning (Ducamp-Collin et al., 2008), but fumigation leaves undesirable residues, alters the fruit taste and may result in health risks to consumer and workers in the packing houses (Hojo et al., 2011).

Acids have been used as an alternative in the prevention of pericarp browning of lychee, especially the hydrochloric acid (Jiang et al. 2004). Other alternatives include the use of ascorbic acid, citric acid, chitosan, lecithin, waxes and plastic packaging (Silva et al. 2,010; Sivakumar \& Korsten, 2006).

This study evaluated the association of acids, cassava starch and PVC films in the reduction of pericarp browning and quality maintenance of 'Bengal' lychees fruits.

\section{MATERIAL AND METHODS}

'Bengal' lychees fruits were harvested with completely red pericarp, in the morning in December 2007. The plants were from the Experimental Orchard, Universidade Fede- ral de Viçosa, Viçosa, Brazil (21 ${ }^{\circ} 07^{\prime} \mathrm{S}, 42^{\circ} 57^{\prime} \mathrm{W}, 651 \mathrm{~m}$ a.s.l.).

Fruits with uniformly red pericarp were selected and immersed in the fungicide prochloraz at concentration of $49.5 \mathrm{~g} / 100 \mathrm{~L}$ of water for five minutes and dried at room temperature.

The fruits were then submitted to the following treatments: a) (immersion in citric acid $100 \mathrm{mM}$ for 5 minutes+ cassava starch $30 \mathrm{~g} \mathrm{~L}^{-1}$ for 5 minutes), b) (immersion in hydrochloric acid $1 \mathrm{M}$ for 2 minutes + cassava starch $30 \mathrm{~g} \mathrm{~L}^{-1}$ for 5 minutes) c) (immersion in citric acid $100 \mathrm{mM}$ for 5 minutes + polyvinyl chloride film (PVC $14 \mu \mathrm{m}$ thick) d) (immersion in hydrochloric acid $1 \mathrm{M}$ for 2 minutes + PVC film) and e) (immersion in distilled water). The fruits from all treatments, including the control, were packed in polystyrene trays (220 mm x $140 \mathrm{~mm} \times 40 \mathrm{~mm})$, in cold storage at $5.0 \pm 1.2^{\circ} \mathrm{C}$ and $90 \pm 5 \% \mathrm{RH}$.

The fruits were evaluated every four days over a period of 20 days for mass loss, pericarp coloration attributes, $\mathrm{pH}$, soluble solids and titratable acidity, vitamin $\mathrm{C}$ in the skin and pulp and pericarp activities of polyphenol oxidase (PPO) and peroxidase (POD).

Gravimetric determination was used to find mass loss and results were expressed as a percentage of fresh mass loss.

The pericarp color was determined by reflectometry, using a Minolta reflectometer (Color Reader CR-10). Two readings were taken per fruit in diametrically opposite positions. The coordinates were $\mathrm{L}^{*}$ (light), ranging from 0 (black) to 100 (white), and $\mathrm{a}^{*}$, ranging from green (-60) to red (+60) (McGuire, 1992).

The pulp $\mathrm{pH}$ was determined by readings from tissue samples in digital pHmeter after grinding in a blender.

PPO and POD activity on pericarp were determined by methods adapted from Maia et al. (2011). The enzyme extract was obtained using $1 \mathrm{~g}$ of pericarp added with $5 \mathrm{ml}$ of $0.2 \mathrm{M}$ phosphate buffer ( $\mathrm{pH}$ 6.0), cooled in an ice bath and triturated in a polytron grinder at $20,500 \mathrm{rpm}$ for $40 \mathrm{~s}$. The suspension was centrifuged at $10,000 \mathrm{~g}$ for 21 minutes at $4{ }^{\circ} \mathrm{C}$. The activity was determined by seven absorbance readings at 30 -seconds intervals in a spectrophotometer $\lambda=425 \mathrm{~nm}$ (PPO) and $\lambda=470 \mathrm{~nm}$ (POD). The results were expressed in enzyme units per gram of sample based on the extract amount that induced an increase in absorbance of 0.01 units per minute.

A factorial design $(2 \times 2)+1$ was used to conduct the experiment, where two acids were combined with two films and a control unit consisting of six fruits. The experiment was arranged in a completely randomized design with three replications. Data were submitted to analysis of variance and regression using the software SAEG 9.1 - System for Genetic Analysis and Statistics. Regression analysis as a function of time was performed for all variables, regardless 
of the significance of the interaction of the factor with time. Descriptive analysis was used for the data of PPO and POD enzyme activity.

\section{RESULTS AND DISCUSSION}

The associations of PVC film with hydrochloric acid and PVC film with citric acid were the treatments that most successfully reduced the loss of fresh fruit matter. At the end of the experimental period these treatments showed fresh matter losses of only 2.68 and $298 \%$, respectively (Figure 1A). In contrast, the combination of hydrochloric acid with cassava starch and the association of citric acid with cassava starch resulted in high percentages of fresh fruit loss, reaching up to 18.56 and $18.38 \%$ on day 20 of storage (Figure 1A). Somboonkaew \& Terry (2010) also report that the application of plastic films on lychee fruits reduces mass loss. However, Campos et al., 2011, showed that the coating with cassava starch associated with chitosan was effective in reducing mass loss in strawberries. Chen et al (2001) stated that a mass loss of $18 \%$ is sufficient to cause total browning of lychee pericarp and, contrarily, Lima et al. (2010), consider that a loss of 3 to $5 \%$ can promote the same effect.

Regarding to light, it was found that the treatments of PVC film associated with hydrochloric acid and the combination of PVC and citric acid (Figure 1B) resulted in a smaller reduction of the $\mathrm{L}^{*}$ values at the end of the experimental period. Fruit color, measured by the parameter $a^{*}$ had smaller alterations in the treatment with the combination of film and hydrochloric acid (Figure 1C) in the last storage days. The parameters $\mathrm{L}^{*}$ and $\mathrm{a}^{*}$ are critical to the successful commercialization of the fruit because the smaller the values of $\mathrm{a}^{*}$, the smaller the intensity of the red colour in the fruit pericarp, while L* represents light/brightness of the pericarp. According to Solomon et al. (2012), an undesirable change in the color of lychee, shown by the rapid reduction in light $\left(\mathrm{L}^{*}\right)$ indicates pericarp browning and loss of intense-red color, and its consequent loss of commercial value.

A decrease in the soluble solids content was observed during all the storage period and in all treatments (Figure 2B). This suggests that there is a reserve consumption due to the metabolic activity of the fruit (Silva et al., 2010). Lima et al. (2011) observed similar behavior, although Hojo et al. (2011) found increased values in soluble solids in 'Bengal' lychee after hydrothermal treatment and hydrochloric acid.

An increase in $\mathrm{pH}$ was observed in fruits of all treatments. However, the starch and hydrochloric acid treatments promoted the highest increments of $\mathrm{pH}$ (Figure $2 \mathrm{~A})$.

There was a reduction in the acidity levels of fruits from all treatments. The treatments with starch and
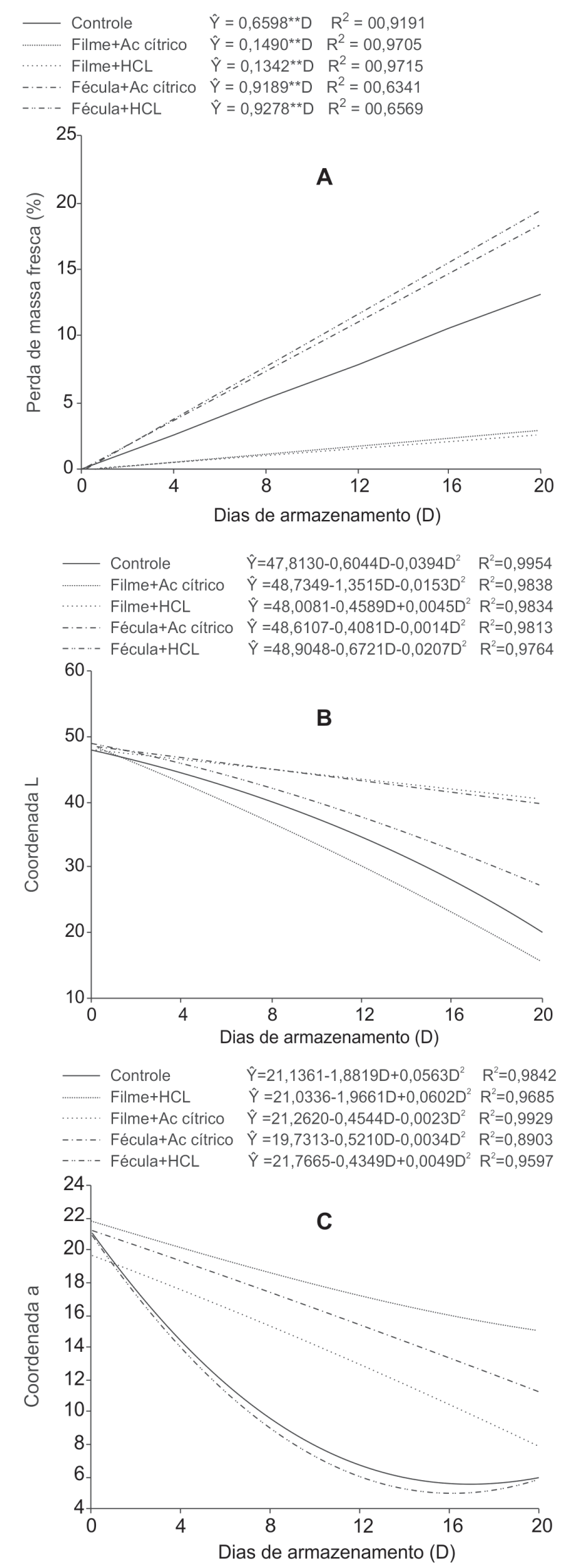

Figure 1. Fresh mass loss (\%) (A); coordinate L* (B); and coordinate $\mathrm{a}^{*}(\mathrm{C})$ of 'Bengal' lychee fruitS stored at $5 \pm 1.2{ }^{\circ} \mathrm{C}$ and $90 \pm 5 \%$ RH for 20 days. 

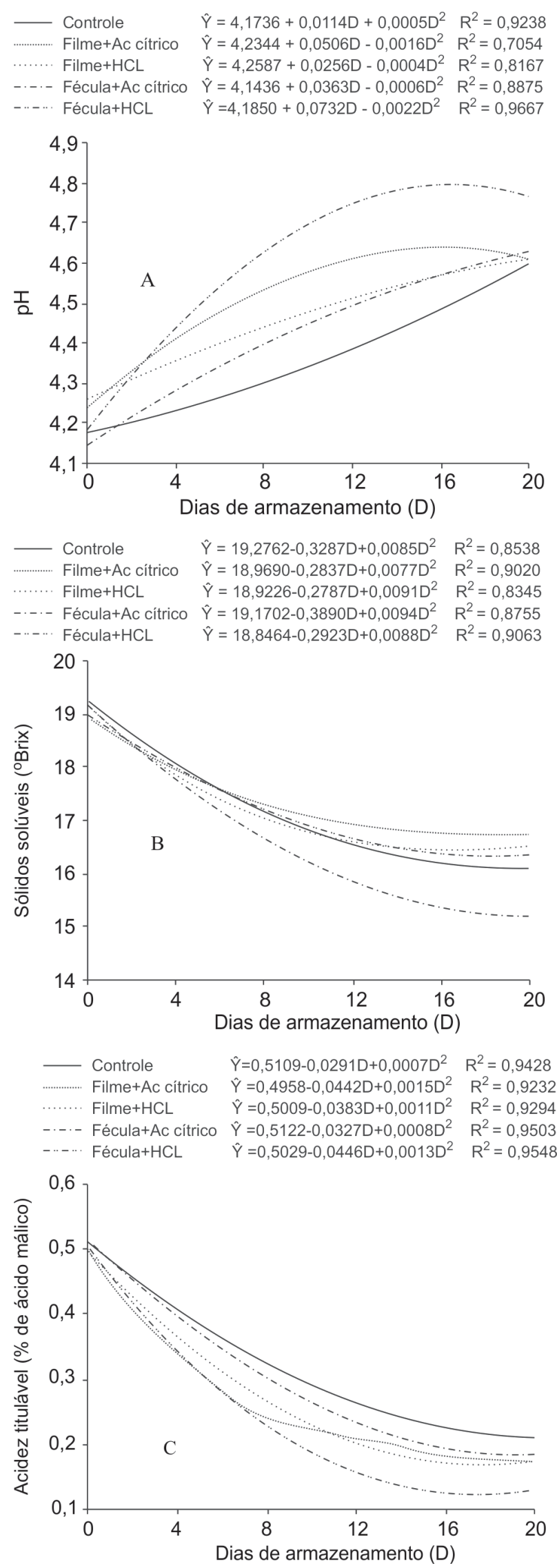

Figure 2. $\mathrm{pH}(\mathrm{A})$, soluble solids $\left({ }^{\circ}\right.$ Brix) (B) and titratable acidity (\% malic acid) (C) of 'Bengal' lychee fruit pulp stored at $5 \pm 1.2$ ${ }^{\circ} \mathrm{C}$ and $90 \pm 5 \% \mathrm{RH}$ for 20 days. hydrochloric acid showed the smallest reductions in the levels of acidity (Figure 2C). This reduction may indicate that organic acids are used as respiratory substrates and as carbon skeletons in the synthesis of new compounds (Reuck et al. May 2011). Hojo et al. (2011) also observed a reduction in the acidity of lychee after hydrothermal treatment and hydrochloric acid.

Reductions in the vitamin $\mathrm{C}$ content of fruit pericarp were observed in all treatments (Figure 3A). In this case, smaller reductions in vitamin $\mathrm{C}$ were found in the fruits treated with hydrochloric acid associated with cassava
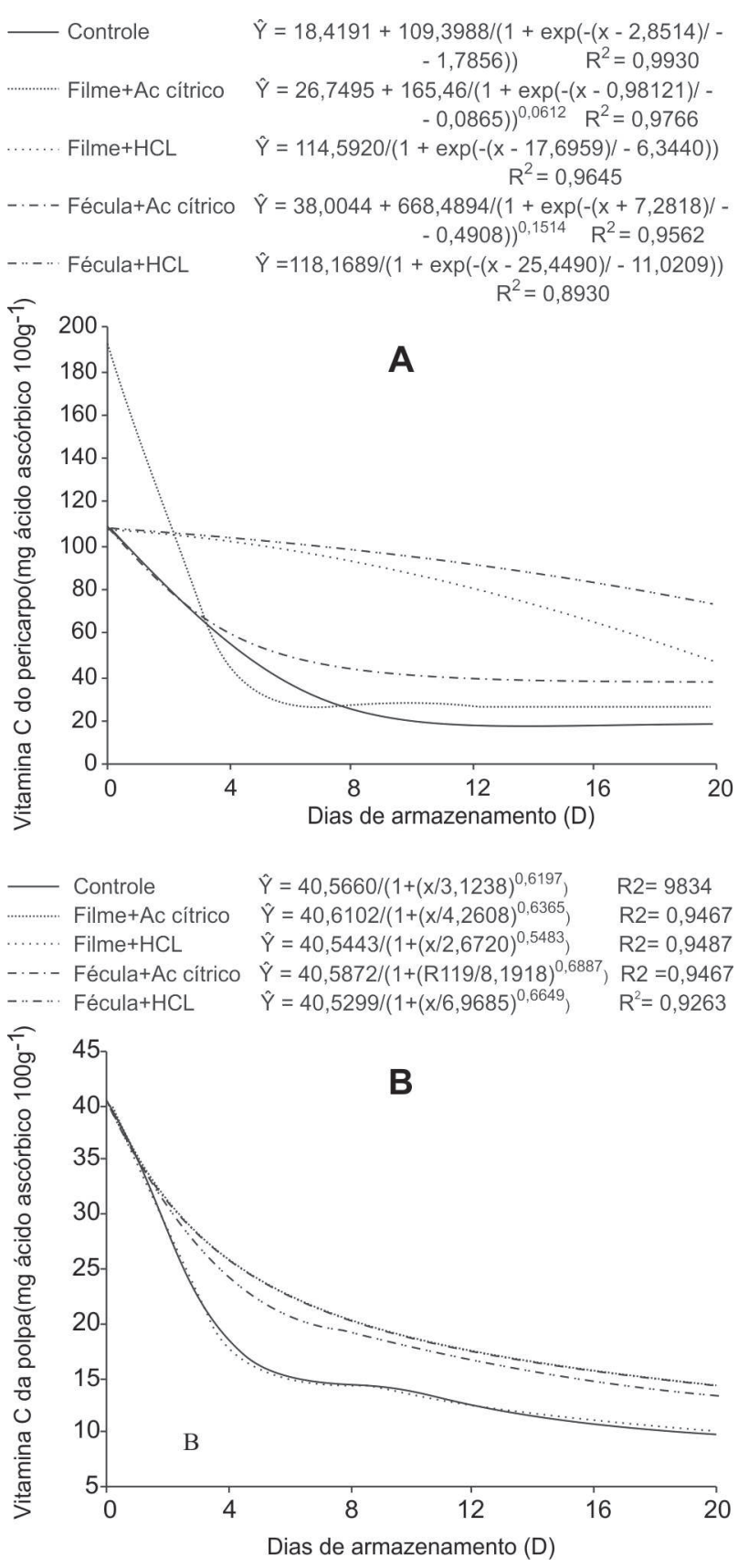

Figura 3. Figure 3. Vitamin $C$ (ascorbic acid $100 \mathrm{mg} \mathrm{g}^{-1}$ ) of pericarp (A) and pulp (B) of 'Bengal' lychee stored at $5 \pm 1.2^{\circ} \mathrm{C}$ and $90 \pm 5 \% \mathrm{RH}$ for 20 days. 
starch and PVC. C. Silva et al. (2010) reported similar behavior in 'Bengal' lychee treated with $30 \mathrm{mM}$ ascorbic acid, as the ascorbic acid is not highly effective in color retention of lychee due to their reversible inhibitory effect on the enzyme.

Smaller reductions in the levels of ascorbic acid were observed in the pulp packaged in PVC associated with acids (Figure 3B). Hojo et al. (2011) found lower levels of ascorbic acid in lychee pulp treated with $1 \%$ hydrochloric acid for six minutes.

On the fourth storage day, the polyphenol oxidase activity increased in fruits of all treatments (Figure 4A), but the combination of hydrochloric acid and PVC film promoted lower enzymatic activity. The same was observed for the peroxidase activity in all treatments and the combination of hydrochloric acid and PVC film also promoted a lower increase in the enzymatic activity (Figure 4B). Silva et al. (2010) also observed that the enzymes were in peak activity on the fourth storage day in lychee treated with different doses of ascorbic acid. An initial increase followed by a subsequent decrease in the activity of POD was observed by Zheng \& Tian (2006) in Huaizhi
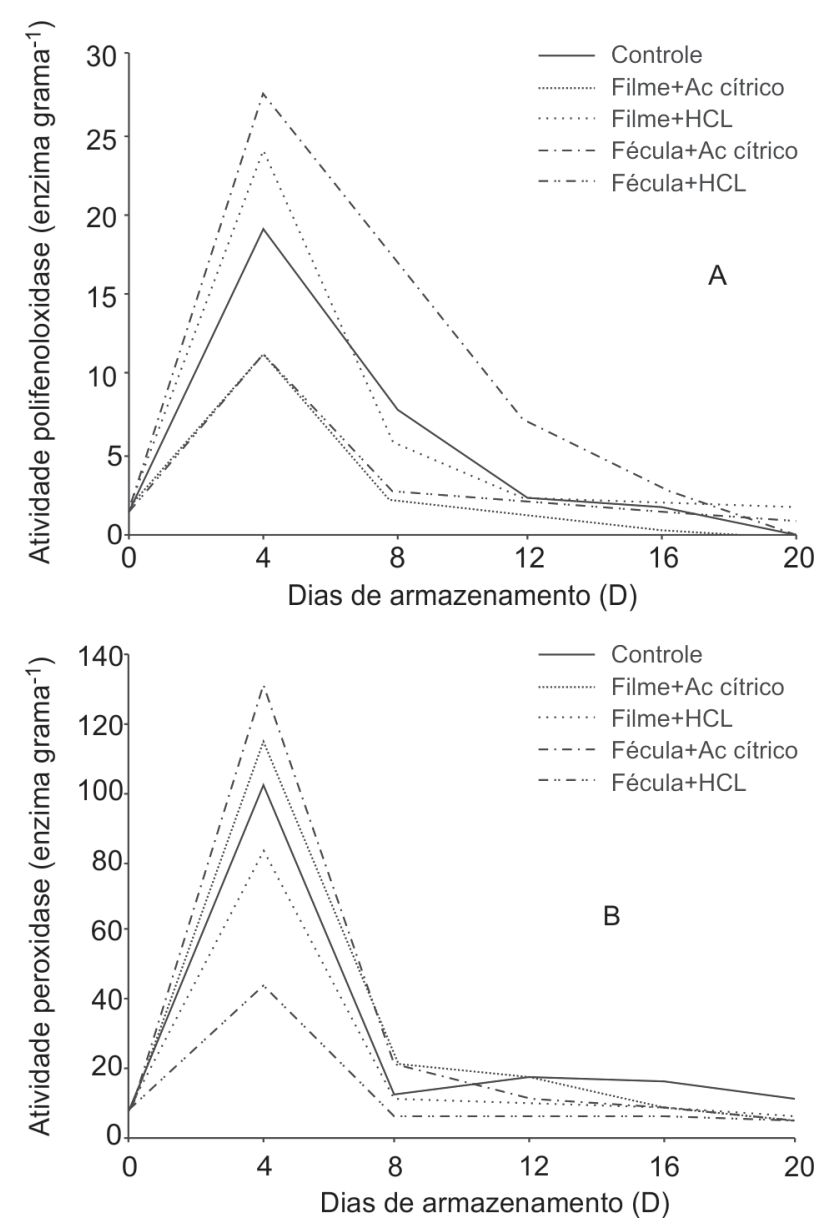

Figure 4. Polyphenol oxidase activity (A) and peroxidase (B) from 'Bengal' lychee pericarp stored at $5 \pm 1.2{ }^{\circ} \mathrm{C}$ and $90 \pm 5 \%$ RH for 20 days. lychee treated with oxalic acid and stored at $25^{\circ} \mathrm{C}$ and $80 \%$ RH for six days. Hojo et al. (2011) also found an increase in PPO activity in lychee between the days 3 and 4 of storage. Zhang et al. (2004) reported high peroxidase activity for lychee cv. Huaizhi on day 4 of storage at $28^{\circ} \mathrm{C}$. Lima et al. (2011) observed an increase of PPO activity on day 10 of storage for lychees treated with ethylene and 1methylcyclopropene.

Based on all the studied characteristics, it was found that the 'Bengal' lychee treated with hydrochloric acid and packaged with PVC film kept the red color of the pericarp similar to the harvest day, maintaining its quality characteristics throughout the experimental period in refrigerated conditions. Therefore, lychee fruits that underwent this treatment were still suitable for consumption, even after 20 days of storage.

\section{CONCLUSIONS}

The treatment with hydrochloric acid associated with PVC was able to maintain the red pericarp color during 20 days and was also the treatment that most preserved the fruit quality characteristics.

The cassava starch associated with the citric acid, and hydrochloric acid did not reduce mass loss and was unable to prevent lychee pericarp browning.

\section{REFERENCES}

Association of Official Analytical Chemists - AOAC (1997) Official methods of analysis of AOAC International. 16 ${ }^{\mathrm{a}}$ ed. Washington, AOAC. 2:37-10, 42-2, 44-3, 45-16.

Campos RP, Kwiatkowski A \& Clemente E (2011) Post-harvest conservation of organic strawberries coated with cassava starch and chitosan. Revista Ceres, 58:554-560.

Chen W, Wu Z, Ji Z \& Su M (2001) Postharvest research and handling of litchi in China - a review. Acta Horticulturae, 558:321-329.

Del Aguila JS, Hofman P, Campbell T, Marques JR, Del Aguila LSH \& Klu-ge RA (2009) Pré-resfriamento em água de lichia 'B3' mantida em armazenamento refrigerado. Ciência Rural, 39:273-2379.

Ducamp-Collin MN, Ramarson H, Lebrun M, Self G \& Reynes M (2008) Effect of citric acid and chitosan on maintaining red colouration of litchi pericarp. Postharvest Biology and Technology, 49:241-246.

Hojo ETD, Durigan JF, Hojo RH, Donadon JR \&Martins RN (2011) Uso do tratamento hidrotérmico e ácido clorídrico na qualidade de lichia "Bengal". Revista Brasileira de Fruticultura, 33:386-393.

Jiang YM, Li Y \& Li J (2004) Browning control, shelf life extension and quality maintenance of frozen litchi fruit by hydrochloric acid. Journal of Food Engineering, 63:147-151.

Lima FV de, Del Aguila JS, Ortega EMM \& Kluge RA (2011) Póscolheita de lichia "Bengal", tratada com etileno e 1metilciclopropeno. Ciência Rural, 41:1-7.

Lima RAZ, Patto de Abreu CM, Asmar SA, Corrêa AD \& Santos CD (2010) Embalagens e recobrimento em lichias (Litchi chinensis Sonn.) armazenadas sob condições não controladas. Ciência e Agrotecnologia, 34:914-921. 
Maia VM, Salomão LCC, Siqueira DL, Puschmann R, Mota Filho VJG \& Cecon PR (2011) Physical and metabolic alterations in prata anã banana induced by mechanical damage at room temperature. Scientia Agrícola, 68:31-36.

McGuire RG (1992) Reporting of objective color measurements. HortScience, 27:1254-1260.

Mizobutsi GP, Finger FL, Ribeiro RA, Puschmann R, Neves LL de M \& Mota WF (2010) Effect of $\mathrm{pH}$ and temperature on peroxidase and polyphenoloxidase activities of litchi pericarp. Scientia Agrícola, 67:213-217

Reuck K de, Sivakumar D \& Korsten L (2011) Integrated application of 1-methylcyclopropene and modified atmosphere packaging to improve quality retention of litchi cultivars during storage. Posthar-vest Biology and Technology, 52:71-77.

Salomão LCC, Silva DFP da, Rocha A, Alves RR \& Matias RGP (2012) Redução do escurecimento do pericarpo de lichia com ácido clorídrico. Revista Brasileira de Fruticultura, 34:568-575.

Salomão LCC, Siqueira DL de, Pereira MEC \& Pereira PRG (2006) Acúmulo de macro e micronutrientes nas inflorescências e frutos da lichieira "Bengal". Ciência Rural, 36:793-800.
Silva DFP da, Cabrini EC, Alves RR \& Salomão LCC (2010) Uso do ácido ascórbico no controle do escurecimento do pericarpo de lichia. Revista Brasileira de Fruticultura 32:618-627.

Sivakumar D \& Korsten L (2006) Influence of modified atmosphere packaging and postharvest treatments on quality retention of litchi Mauritius. Postharvest Biology and Technology, 41:135-142.

Somboonkaew N \& Terry LA (2010) Physiological and biochemical profiles of imported litchi fruit under modified atmosphere packaging. Postharvest Biology and Technology, 56:246-253.

Zhang ZQ, Pang XQ, Yang C, Ji ZL \& Jiang YM (2004) Purification and structural analysis of anthocyanins from litchi pericarp. Food Chemistry, 84:601-604.

Zheng XL \& Tian SP (2006) Effect of oxalic acid on control of postharvest browning of litchi fruit. Food Chemistry, 96:519523 . 